\title{
The Influence of Realistic Mathematical Approach on Creative Thinking Ability and Mathematical Problem Solving Students in Class VIII
}

\author{
Abdul Halim Asmin Faiz Ahyaningsih Adek Safitri \\ State University of Medan, North Sumatera, Indonesia
}

\begin{abstract}
This study aims to determine the effect of a realistic mathematical approach on students' mathematical creative thinking abilities, to determine the effect of a realistic mathematics approach on students' mathematical problem solving abilities, to determine the interaction between learning and initial mathematics ability (KAM) on students' mathematical creative thinking abilities, and know the interaction between learning and early mathematics abilities (KAM) on students' math problem solving abilities. The data were obtained through the KAM test, tests of creative thinking questions and student problem solving. Data were analyzed using two-way ANOVA test. Based on the results of the analysis (ANAVA), the results of the study with a significant value ( $\mathrm{sig}) \alpha=0.000$ concluded that there was an effect of a realistic mathematics learning approach on students 'creative thinking abilities and the significance value of the interaction was 0.488 , meaning that there was no interaction between learning approaches and KAM on students' creative thinking abilities. . Furthermore, for the problem solving ability the significant value ( $\operatorname{sig}) \alpha=0.000$ that there is an effect of the realistic mathematics learning approach on students' mathematical problem solving abilities and the interaction significance value is 0.337 because the significance value is greater than the significant level value 0.05 so there is not enough evidence to reject it. Ho in other words Ho is accepted, meaning that there is no interaction between learning approaches and KAM on students' mathematical problem solving abilities.
\end{abstract}

Keywords: Realistic Mathematical Approach, Creative Thinking Ability, Problem Solving Ability, Early Mathematical Ability (KAM)

DOI: $10.7176 / \mathrm{JEP} / 11-27-02$

Publication date:September $30^{\text {th }} 2020$

\section{Introduction}

Mathematics is a subject that plays a very important role in education. Because in addition to being able to develop creative, creative, systematic, and logical thinking, mathematics has also contributed to everyday life ranging from simple things such as basic calculations to complex and abstract matters such as the application of numerical analysis in engineering and so. Through good mathematics education, students can indeed obtain various kinds of provisions in facing challenges in the global era. In the 2013 curriculum itself, the use of technology in learning became something that was highly recommended. The learning process in the 2013 curriculum requires students to participate actively and provide sufficient space for students' creativity, interests, and talents (Fitri, Syahputra, \& Syahputra, 2019).

Improving the quality of mathematics learning in Indonesia, according to the demands of the 2013 curriculum, requires various efforts. Educational design that provides opportunities for students to develop their potential in a fun learning atmosphere and in accordance with their abilities. Along with the development of the internet, the learning strategy has shifted and various information and communication technology-based learning strategies have emerged from the e-learning model, smart classroom technology, virtual classroom, belded learning, etc. (Fitri \& Zahari, 2019). The teacher acts as a facilitator in learning. The assessment process is based on process and output and balances soft skills and hard skills. One of the hard skills that is required is the ability to think creatively.

One of the doing math which is closely related to the characteristics of mathematics is the ability to think creatively and solve problems. The ability to think creatively is characterized by students who are more inclined to ask questions that can help them find answers when solving a problem. Students will easily have the ability to think creatively in mathematics if when they receive lessons, the methods given to them can develop their thinking and creativity through a strategy and approach that the teacher uses.

Semiawan (2010) who argues that creativity is the ability to provide new ideas and apply them in problem solving. This means that someone who has high creativity is someone who can create or provide new ideas in solving problems. In mathematics, for example, students can use their creativity in making solutions that are new and different from others, but still in the right context. From the above understanding, it is concluded that creativity is the ability that a person has to create something new in the form of ideas and ideas that produce new work.

The creative process will only occur if it is raised through problems that lead to five kinds of creative behavior, as described by Parnes in Rachmawati and Kurniati (2010) as follows:

a. Fluency (fluency), namely the ability to come up with similar ideas to solve a problem. 
b. Flexibility (flexibility), namely the ability to generate various kinds of ideas in order to solve a problem outside the usual category.

c. Orginality, which is the ability to give a unique or extraordinary response.

d. Elaboration (clarity), namely the ability to express detailed direction of ideas to bring ideas into reality.

Likewise with the importance of having problem-solving skills in solving math problems. In solving problems, of course there are problems that will be resolved. A problem can be interpreted as a situation, where someone is asked to solve a problem that has never been worked on, and does not yet understand the solution. A math problem or statement will be a problem if there are no specific rules or laws that can be used immediately to answer or solve it. A problem is called a mathematical problem if mathematical procedures such as arithmetic and algebra procedures are required to solve it. Hudojo (2005) argues that problem solving is essential in learning mathematics in schools, because: (1) students become skilled at selecting relevant information, then analyze it and finally examine the results; (2) intellectual satisfaction will arise from within; (3) students' intellectual potential increases. Thus, solving this problem should receive special attention, given its very important role in developing students' intellectual potential.

Problem solving is considered a standard ability that students must have after completing a lesson. Problem solving ability is an ability which is the target of learning mathematics which is very useful for students in their lives. This is because the problem solving abilities provided by students indicate that learning has been able or successful in helping students to achieve the goals to be achieved. Polya in Dinda (2012), operationally problem solving has the following stages: (1) Understanding the problem, (2) Planning the solution, (3) Resolving the problem according to the plan (4) Re-checking the procedure and the results of the solution.

The learning atmosphere developed so far also still uses conventional learning models and tends to demand that students be competitive where teachers have not organized and created a good learning atmosphere and are still teacher-centered. Learning that takes place has not actively involved students, does not accommodate individual differences, self-concept or looking at the child's personality, this can be seen from selecting the same strategy for a group of students who of course have different needs and characteristics.

Good teachers are teachers who have pedagogical competence. Pedagogical competence has seven aspects, namely (1) mastering the characteristics of students; (2) mastering learning theory and teaching learning principles; (3) curriculum development; (4) educational learning activities; (5) developing the potential of students; (6) communication with students; and (7) Assessment and evaluation.

Children are more interested if they directly see the mathematical process in the field or are realistic so that they always use mathematics with their personal needs in the field. The Realistic Mathematical Approach (PMR) is a mathematics learning approach that must always use everyday problems (Wijaya, 2012). Mathematics learning activities in the PMR principle do not always have to be problems that exist in the real world but are commonly found in everyday life. students 'day. A problem is called realistic if the problem can be imagined or real in students' minds. A fictional story, game or even a formal form of mathematics can be used as a realistic problem. In PMR, realistic problems are used as a foundation in building mathematical concepts, also known as sources for learning.

Meanwhile, the characteristics of students who are right are given by PMR, namely: (1) actively understanding problems / questions, (2) active in mathematics, (3) actively asking questions, (4) actively finding mathematical models / strategies / procedures (5) actively solving problems, (6) actively comparing models / strategies / procedures. The main idea of the RME learning model is that humans should be given the opportunity to reinvent mathematical ideas and concepts with adult guidance (Gravemeijer, 1994). Efforts to reinvent mathematical ideas and concepts are made by utilizing reality and the environment close to children.

A further explanation is put forward by Van den Heuvel (Wijaya, 2012) that the use of the word "realistic" actually comes from the Dutch "zich realiseren" which means to be imagined. Thus, RME does not only show a connection with the real world but refers more to the focus of realistic mathematics education, namely the emphasis on the use of situations that can be imagined by students.

The steps for the core realistic mathematics learning activities in this study are as follows.

\section{Step 1: Understand contextual issues.}

The teacher provides contextual problems and students are asked to understand the problem. The teacher explains the problem or problem by giving instructions / suggestions as needed (limited) to certain parts that are understood by students. In this step, the PMR characteristics applied are the first characteristics. Apart from that, providing contextual problems means giving the opportunity to implement the first principles of PMR.

\section{Step 2: Resolving contextual problems.}

Individual students are asked to solve contextual problems in the Student Book or LKS in their own way. Different ways of solving and answering the problem are preferred. The teacher motivates students to solve the problem by giving guiding questions to direct students to solve the problem. For example: how do you know that, how do you do it, why do you think like that, etc. At this stage students are guided to rediscover the idea or concept or definition of a math problem. In addition, at this stage students are also directed to form and use their own models to form and use their own models to make it easier to solve problems (questions). The teacher is expected not to tell the 
problem or problem solving before students get their own solution. In this step all the PMR principles emerge, while the PMR characteristics that emerge are the second characteristics, using the model.

\section{Step 3: Compare and discuss answers}

Students are asked to compare and discuss their answers in small groups. After that the results of the discussion are compared to classroom discussions led by the teacher. At this stage students can use it to train the courage to express their opinions, even though they are different from other friends or even their teachers. The characteristics of PMR that appear at this stage are the use of ideas or student contributions, as an effort to activate students through optimizing interactions between students and students, between teachers and students and between students and learning resources.

\section{Step 4: Draw Conclusions}

Based on the results of group discussions and class discussions, the teacher directs students to draw conclusions about mathematical concepts, definitions, theorems, principles or procedures related to contextual problems that have just been solved. The PMR characteristics that appear in this step are to use interactions between teachers and students.

According to Suwarsono: (2001) there are several strengths or advantages of realistic mathematics, namely:

a. Realistic mathematics learning provides clear understanding to students about everyday life and its general use for humans.

b. Learning realistic mathematics gives a clear understanding to students that mathematics is a field of study that is constructed and developed by students themselves, not only by those who are called experts in the field.

c. Realistic mathematics learning provides a clear understanding to students how to solve a problem or problem does not have to be single and does not have to be the same from one person to another. Everyone can find or use their own way, as long as that person is serious about working on the problem or problem. Furthermore, by comparing one solution with another, an appropriate solution will be obtained, in accordance with the objectives of the problem solving process.

d. Realistic mathematics learning provides a clear understanding for students that the learning process of mathematics is the main thing. And people must go through that process and try to find mathematical concepts themselves with the help of others who already know better (for example teachers). Without the will to go through the process yourself, meaningful learning will not be achieved.

Therefore, the Realistic Mathematical Approach (PMR) is one of the best lessons in learning mathematics, because in this learning it relates subject matter to everyday life, so that students can apply subject matter to everyday life. Making students more stimulated in learning mathematics. Based on the background description, the researcher is interested in conducting research to reveal whether there is an effect of the realistic mathematical approach on the ability to think creatively and solve math problems of students in class VIII.

\section{Methods}

This study took two parallel classes at random by applying different learning, namely the experimental class and the control class. The experimental class was treated by applying the PMR approach and the control was treated by applying conventional learning. The experimental design in this study can be described as follows:

Table 1. Research Design

Information :

\begin{tabular}{|l|c|c|}
\hline \multicolumn{1}{|c|}{ Group } & Independent Variable & Postest \\
\hline Experiment & $\mathrm{X}$ & $\mathrm{O}$ \\
\hline Control & & $\mathrm{O}$ \\
\hline
\end{tabular}

$\mathrm{X}$ : Treatment in the form of a PMR approach using a concept map

O: Postest experimental group and control group

The population in this study were all students at MTs Private At-taufiqurrahman academic year 2017/2018, totaling 174 students. The research sample was taken randomly in two classes, namely the experimental class and the control class. The experimental class is a class treated with the PMR approach. And the control class is a class that is given conventional-based learning. The samples in this study are class VIII-1 and class VIII-2. Class VIII1 as the experimental class consisted of 25 students and class VIII- 2 as the control class consisted of 25 students.

The research instrument used was a test of creative thinking and problem solving, which was used in the posttest to measure students' abilities which were used to determine creative thinking and problem solving. There are 4 test questions that will be given in the form of descriptions because the test in essay form can represent all indicators of students' mathematical creative thinking abilities. This research is equipped with observation sheets on teacher and student activities, especially teacher pedagogical abilities in a realistic mathematics approach, as well as observation sheets on students' problem solving skills and creative thinking skills while working in groups based on procedural knowledge.

This study uses inferential statistical analysis of two-way analysis of variance (ANOVA) or what is called Anava more than one path (Two Ways Analysis of Variance). This inferential statistical analysis is used to test the 
comparison as well as regression with the fulfillment of 2 requirements, namely the research sample is normally distributed and the research sample is homogeneous.

\section{Result And Discussion}

Students' mathematical problem solving abilities were obtained from the posttest results in the experimental class and the control class. Based on the results of the posttest given during learning in the experimental class and the control class, then the average and standard deviation of the students' creative thinking ability test results were calculated. The results of the student's creative thinking ability test can be seen in Figure 1 below:

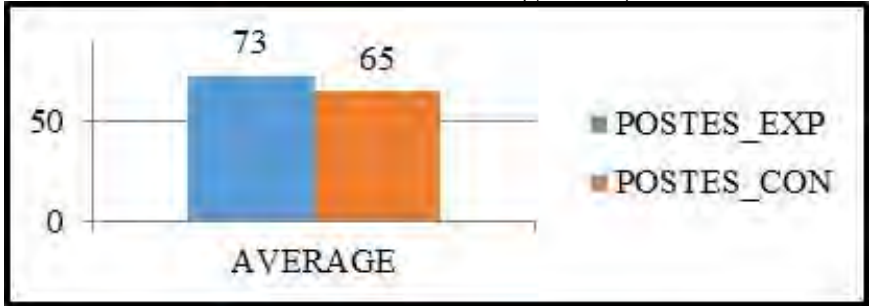

Figure 1. Graph of the Average Post-Test of Mathematical Creative Thinking Ability in the Experiment Class and the Control Class

The results of students' creative thinking ability tests based on indicators can be seen in Table 2 .

Table 2. Posttest Results of Creative Thinking Ability Based on Indicators

\begin{tabular}{|l|c|c|}
\hline \multirow{2}{*}{ Indicator } & \multicolumn{2}{|c|}{ Average } \\
\cline { 2 - 3 } & $\begin{array}{c}\text { Posttest Experiment } \\
\text { Class }\end{array}$ & $\begin{array}{c}\text { Posttest Control } \\
\text { Class }\end{array}$ \\
\hline $\begin{array}{l}\text { Fluency thinking : Able to answer with a number of } \\
\text { answers }\end{array}$ & 7,48 & 6,96 \\
\hline $\begin{array}{l}\text { Flexible Thinking: Able to solve problems with a variety of } \\
\text { solutions. }\end{array}$ & 9,84 & 9,52 \\
\hline $\begin{array}{l}\text { Original Thinking: able to provide new ideas in solving } \\
\text { problems }\end{array}$ & 11,32 & 10,24 \\
\hline $\begin{array}{l}\text { Elaborative Thinking: tends to provide broad and satisfying } \\
\text { answers }\end{array}$ & 7,9 & 5,8 \\
\hline
\end{tabular}

Table 2 shows that the average creative thinking ability of students after being given realistic mathematics learning is better than the average creative thinking skills of students who are given conventional learning. The average posttest of the experimental class and control class posttest for the first indicator is 7.48 and 6.96 , the second indicator is 9.84 and 9.52, the third indicator is 11.3 and 10.24 , the fourth indicator is 7.9 and 5,8 .

Based on the description above, it can be seen that the post-test average creative thinking ability of the experimental class students for each indicator is better than the post-test average creative thinking ability of the control class students. This suggests that there is a better impact on students who are given realistic mathematics learning.

The test results show that the creative thinking ability data group comes from a normally distributed population with homogeneous data variance, then a two-way analysis of statistical analysis is carried out.

Table 3. Results of the ANAVA Test for Students' Creative Thinking Ability

\begin{tabular}{|l|r|r|r|r|r|}
\hline \multicolumn{7}{|c|}{ Tests of Between-Subjects Effects } \\
\hline Dependent Variable: Creative Thinking Ability \\
\hline Source & Type III Sum of Squares & Df & Mean Square & \multicolumn{1}{c|}{ F } & Sig. \\
\hline Corrected Model & $4607.280^{\mathrm{a}}$ & 5 & 921.456 & 37.196 & .000 \\
\hline Intercept & 151919.582 & 1 & 151919.582 & 6132.534 & .000 \\
\hline KAM & 3738.809 & 2 & 1869.405 & 75.462 & .000 \\
\hline Pembel & 525.523 & 1 & 525.523 & 21.214 & .000 \\
\hline KAM * Pembel & 36.151 & 2 & 18.075 & .730 & .488 \\
\hline Error & 1090.000 & 44 & 24.773 & & \\
\hline Total & 244576.000 & 50 & & & \\
\hline Corrected Total & 5697.280 & 49 & & & \\
\hline a. R Squared $=.809$ (Adjusted R Squared $=.787)$ \\
\hline
\end{tabular}

Based on the results of the ANOVA test, students' creative thinking abilities in table 4.8 then $\mathrm{F}$ count on the realistic mathematics learning approach factor is 21.214 and the significant value (sig) $\alpha=0.000$. Because the significant value level of students 'creative thinking abilities is smaller than $\alpha=0.05$, it can be concluded that there is an effect of a realistic mathematics learning approach on students' creative thinking abilities. 
For the interaction from Table 3, it can be seen that the learning factor and KAM from the analysis results, the $\mathrm{F}$ value for the interaction of learning and KAM is 0.730 and a significance value is 0.488 . Because the significance value is greater than the significant level value of 0.05 , so there is not enough evidence to reject Ho, in other words $\mathrm{H} 1$ is accepted, it means that there is no interaction between learning approaches and KAM on students' creative thinking abilities. More clearly can be seen in the following image:

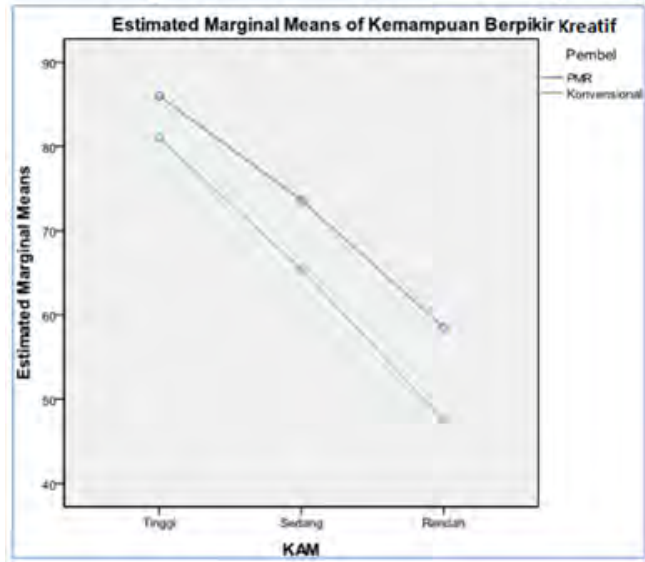

Figure 2. Interaction of Learning Approaches and Early Mathematics Ability to Students' Creative Thinking Ability

Figure 2 shows that the realistic mathematics learning approach is more influential in achieving the potential for creative thinking abilities because the average score obtained by students in this class is higher than the average score obtained in conventional learning. So that there is no interaction between the learning approach and the students 'initial mathematical abilities on students' creative thinking abilities. Based on some of the descriptions above, the answers to the questions that must be examined in this study have been obtained. That the two lines do not intersect or intersect, it is strongly suspected that there is no interaction between the learning model and KAM on students' mathematical creative thinking abilities.

Based on the results of the posttest given after learning to the two classes, namely the experimental class for learning realistic mathematics approaches and the control class for ordinary learning, then calculating the average and standard deviation of the results of the students' mathematical problem-solving ability test results. The results of the test for students' mathematical problem solving abilities can be seen in Figure 3 below:

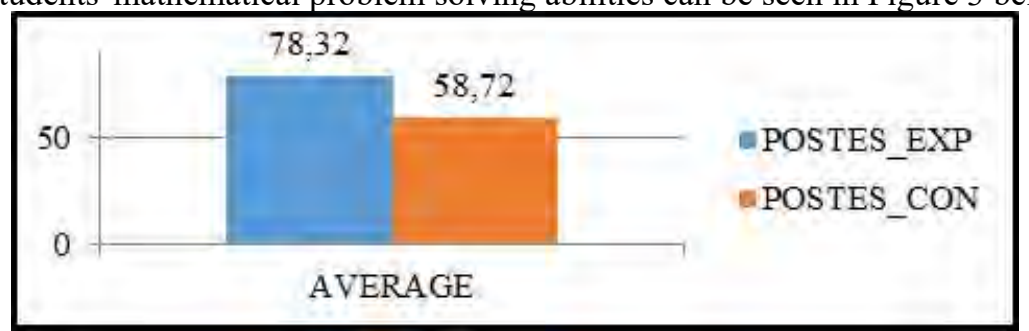

Figure 3.Graph of Average Posttest of Mathematical Problem Solving Ability in Experiment Class and Control Class

The magnitude of the effect of the test results on students' mathematical problem solving abilities can also be seen based on the indicators on their mathematical problem solving abilities. The results of students' mathematical problem solving abilities based on indicators can be seen in Table 4. 
Table 4. Posttest Results of Mathematical Problem Solving Ability Based on Indicators

\begin{tabular}{|c|c|c|}
\hline \multirow{2}{*}{ Indicator } & \multicolumn{2}{|c|}{$\begin{array}{l}\text { Group Posttest } \\
\text { Learning }\end{array}$} \\
\hline & Experiment & Control \\
\hline \multicolumn{3}{|l|}{ Understanding the Problem } \\
\hline $\begin{array}{l}\text { Known } \\
\text { - Write down what is known correctly and completely }\end{array}$ & 5 & 5 \\
\hline $\begin{array}{l}\text { Adequacy of Data } \\
\text { - Write down sufficient data correctly }\end{array}$ & 9.96 & 9.8 \\
\hline \multicolumn{3}{|l|}{ Plan for Settlement } \\
\hline $\begin{array}{l}\text { - Write down the methods used to solve the problem correctly and } \\
\text { completely. }\end{array}$ & 12.2 & 11 \\
\hline \multicolumn{3}{|l|}{ Carry out the Plan } \\
\hline - Write down the completion rules with correct and complete results & 5.96 & 2 \\
\hline \multicolumn{3}{|l|}{ Check again } \\
\hline - Write down the examination correctly and completely & 6 & 1.8 \\
\hline
\end{tabular}

Based on the description above, it can be seen that the average test of students 'mathematical problem-solving abilities in the experimental class for each indicator is greater than the average test of students' mathematical problem-solving abilities in the control class. This shows that there is a better effect on students who are given realistic mathematics approach learning.

The test results show that the data group of students' mathematical problem solving abilities comes from a population that is normally distributed with homogeneous data variance.

Table 5. ANOVA Test of Students' Mathematical Problem Solving Ability

\begin{tabular}{|l|c|c|c|c|c|c|}
\hline \multicolumn{6}{|c|}{ Tests of Between-Subjects Effects } \\
\hline \multicolumn{2}{|c|}{ Dependent Variable: Mathematical_Problem Solving Ability } \\
\hline Source & Type III Sum of Squares & Df & Mean Square & F & Sig. \\
\hline Corrected Model & $6292.141^{\mathrm{a}}$ & 5 & 1258.428 & 79.949 & .000 \\
\hline Intercept & 189522.111 & 1 & 189522.111 & $1.204 \mathrm{E} 4$ & .000 \\
\hline PEMBELAJARAN & 3206.111 & 1 & 3206.111 & 203.686 & .000 \\
\hline KAM & 1834.600 & 2 & 917.300 & 58.277 & .000 \\
\hline PEMBELAJARAN * KAM & 35.110 & 2 & 17.555 & 1.115 & .337 \\
\hline Error & 692.579 & 44 & 15.740 & & \\
\hline Total & 243932.000 & 50 & & & \\
\hline Corrected Total & 6984.720 & 49 & & & \\
\hline a. R Squared = 901 (Adjusted R Squared $=.890)$ & & & & \\
\hline
\end{tabular}

Based on the results of the ANOVA test, students' mathematical problem solving abilities are in table 4.11. then $\mathrm{F}$ count on the realistic mathematics learning approach factor is 203.686 and the significant value (sig) $\alpha=$ 0.000 . Because the significant value level of students 'problem solving abilities is smaller than $\alpha=0.05$, it can be concluded that there is an effect of a realistic mathematics learning approach on students' mathematical problem solving abilities.

For the interactions from Table 5. It can be seen that the learning factor and KAM analysis results show that the F value for the interaction of learning and KAM is 1.115 and the significance value is 0.337 . Because the significance value is greater than the significant level value of 0.05 , so there is not enough evidence to reject Ho, in other words Ho is accepted, it means that there is no interaction between learning approaches and KAM on students' mathematical problem solving abilities. More clearly can be seen in the following image: 
Estimated Marginal Means of KEMAMPUAN Pemecahan Masalah

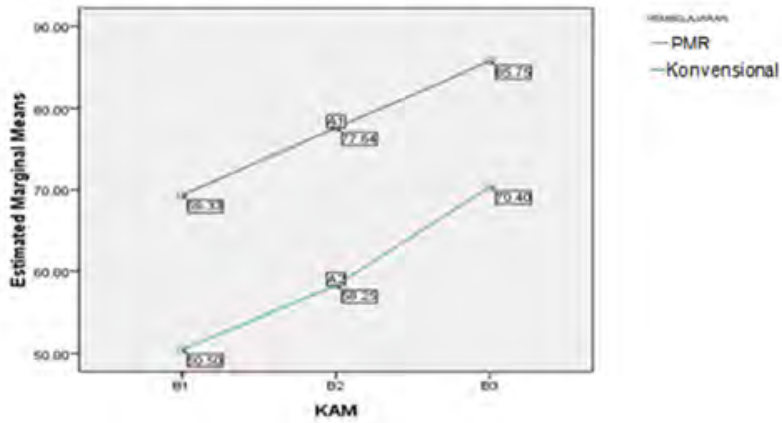

Figure 4. The Interaction of Learning Approaches and Early Mathematics Ability to Students' Problem Solving Ability

Figure 4 shows that the realistic mathematics learning approach is more influential in achieving the potential of students' mathematical problem solving abilities because the average score obtained by students in this class is higher than the average score obtained in conventional learning. So that there is no interaction between the learning approach and the students 'initial mathematical abilities to the students' mathematical problem solving abilities.

Based on some of the descriptions above, the answers to the questions that must be examined in this study have been obtained. That the two lines do not intersect or intersect, it is strongly suspected that there is no interaction between the learning model and KAM on students' mathematical problem solving abilities.

The KAM test in this study was used to determine student KAM groups based on high, medium, and low KAM groups. KAM grouping is also used to answer problems related to creative thinking skills and mathematical problem solving abilities that are taught using realistic mathematics approaches and ordinary learning.

In obtaining new learning, students must use the knowledge and experience they already have to participate in further learning. The things that have been learned will be used to deal with or solve new things. For this reason, so that students can achieve good learning outcomes, first, they are given an initial mathematical ability test so that they can find out what knowledge, skills, and competencies the students already have when they are going to take part in the teaching.

Thus the height or breadth of knowledge, information, experience and students 'abilities that will be used to learn the next lesson is expected to increase the possibility of increasing students' creative thinking skills and mathematical problem solving abilities.

Students who are creative are different from students who are less creative. Creative students are more inclined to ask questions that can help them find answers when solving a problem. Students will easily have the ability to think creatively in mathematics if when they receive a lesson, the method given to them can develop their thinking and creativity through a strategy used by the teacher. As explained on the previous page, that creative thinking is a pattern of thinking that is based on a way that encourages creative products to be produced. This means that students who think creatively will always try to find solutions to different and varied problems.

So, the purpose of the ability to think creatively in mathematics is the ability a person has to be able to solve a mathematical problem by having a variety of and varied ways of solving answers by taking into account the quality of the answer. So, learning mathematics is felt not monotonous and boring.

According to Purba, Surya and Syahputra (2017) analyzed that students had difficulty working on FPB questions because students could not perform multiplication and division operations. This is because students do not have the ability to think creatively. Nehe, Surya, and Syahputra (2017) state that students 'creative thinking skills can improve students' mathematical understanding. Meanwhile, according to Simbolon, Manullang, Surya, and Syahputra (2017), the ability to think creatively will improve students' problem solving abilities as well.

Based on the results of the ANOVA test, students' creative thinking skills with a significant value (sig) $\alpha=$ 0.000 . Because the significant value level of students 'creative thinking abilities is smaller than $\alpha=0.05$, it can be concluded that there is an effect of a realistic mathematics learning approach on students' creative thinking abilities.

As stated earlier, what is meant by mathematical problem solving ability is the ability of students to solve a problem. Students are said to have good mathematical problem solving skills if they have been able to: (1) identify known elements and ask questions; (2) formulating mathematical problems or compiling mathematical models; and (3) selecting and implementing strategies to solve problems.

In this study, private MTs Attaufiqurrahman Labuhan batu Utaradara was conducted with a population of all students of class VIII MTs Private Attaufiqurrahman Labuanbatu Utar and samples taken randomly (cluster sampling) to be used as experimental class were VIII-1 and the control class was VIII-2.

The purpose of this study is to answer problem formulations and hypotheses (provisional assumptions), namely to find out whether the ability to solve mathematical problems using realistic mathematics approach learning is better than ordinary learning. Before the statistical test for the hypothesis was carried out using the t- 
test assisted by SPSS 23, the post-test data for normality and homogeneity was carried out. The results showed normal and homogeneous based on the normality and homogeneity tests using SPSS 23.

Sinaga, Surya and Syahputra (2017) found that there was an effect of the Realistic Mathematical Education (RME) approach on students' problem solving-based mathematical communication skills. Sofiyah, Surya and Syahputra (2017) said that a realistic mathematics education approach can improve or build mathematical problemsolving abilities and student learning independence. According to Syahputra (2017), it is necessary to develop a problem-solving based learning model to construct higher-order thinking in mathematics learning in SMA / MA. Siregar, Surya and Syahputra (2017) students need to have problem solving skills so that students are able to choose and develop the right strategy to solve problems. Landong, Surya and Syahputa (2017) said that problem solving abilities can increase the positive character of students. So, it is important to always improve students' problem-solving abilities. Meanwhile, according to Putri, Syahputra, and Surya (2017) it is important to improve the problem-solving abilities of students at SMP Negeri 2 Lubuk Pakam.

Based on the results of the ANOVA test, students' mathematical problem solving abilities are in table 5 then the significant value (sig) $\alpha=0.000$. Because the significant value level of students 'problem solving abilities is smaller than $\alpha=0.05$, it can be concluded that there is an effect of a realistic mathematics learning approach on students' mathematical problem solving abilities.

In this study, students' abilities were also obtained based on the KAM score, in which the grouping of students was based on high, medium and low abilities. Student ability factor, namely KAM, is associated with learning factors. So it can be seen how the relationship between KAM and learning towards creative thinking skills and mathematical problem solving abilities of students. Students will use their previous knowledge. This is in accordance with Piaget's theory of cognitive development, Piaget said that knowledge is formed by the individual himself. Students can learn with prior knowledge. Furthermore, Vygostky said that learning occurs when children work or learn to handle tasks that have not yet been learned but are still within their own range.

From the results of data analysis, the ability to think mathematically creative in the field is obtained with a significance level of 0.488 . Thus, H0 is accepted and $\mathrm{H} 1$ is rejected. Which means that there is no interaction between learning and students 'initial mathematics ability to students' mathematical creative thinking abilities. This means that the interaction between learning and students 'initial mathematics ability (KAM) does not have a significant effect on students' mathematical creative thinking abilities.

Likewise, the students' problem solving abilities, the results of data analysis obtained in the field, showed that the significance level was 0.337 . Thus $\mathrm{H} 0$ is accepted and $\mathrm{H} 1$ is rejected. Which means that there is no interaction between learning and students 'initial mathematical abilities on students' problem solving abilities.

The results of this study indicate that there is significantly no interaction between learning and early mathematics ability (KAM) on creative thinking skills and mathematical problem solving abilities. This means that learning in influencing students 'creative thinking abilities and mathematical problem solving abilities does not depend on students' initial mathematical abilities (learning and KAM do not influence each other). In other words, the influence of creative thinking skills and students 'mathematical problem solving abilities is caused by the learning used and does not depend on students' initial mathematical abilities. So it can be concluded that the absence of interaction between learning and students 'initial mathematical abilities does not jointly influence students' creative thinking skills and mathematical problem solving abilities.

\section{Conclusion}

The Based on the results of data analysis and discussion in this study, the following conclusions are stated:

1. There is an effect of a realistic mathematics learning approach on students' creative thinking abilities. Based on the analysis results obtained Fcount $=21.214>$ Ftable $=3.02$ with sig $=0.000$. Because the level of sig. smaller than 0.05 , so that Ho is rejected and $\mathrm{H} 1$ is accepted. So it can be concluded that there is an effect of a realistic mathematics learning approach on students' creative thinking abilities.

2. There is an effect of a realistic mathematics learning approach on students' mathematical problem solving abilities. Based on the analysis results obtained Fcount $=203.686>$ Ftable $=3.02$ and with sig $=0.000$. Because the level of sig. smaller than 0.05 , so that Ho is rejected and $\mathrm{H} 1$ is accepted. So it can be concluded that there is an effect of a realistic mathematics learning approach on students' mathematical problem solving abilities.

3. There is no interaction between learning and early mathematics abilities on students' creative thinking abilities. Based on the analysis results obtained Fcount $=0.730<$ Ftable $=3.02$ and with sig $=0.488$. Because the sig level is greater than the significant level of 0.05 , so Ho is accepted.

4. There is no interaction between learning and early mathematics abilities on students' mathematical problem solving abilities. Based on the analysis results obtained Fcount $=1.115<$ Ftable $=3.02$ and with sig $=0.337$. Because the level of sig. greater than the significant level value of 0.05 so that Ho is accepted.

\section{References}

Andriani, A. (2017). Interaction between Learning Models and Early Mathematics Ability to Increase 
Mathematical Problem Solving Ability. Thesis. UNIMED: Medan.

Charles Chaeffer. (2000). How to Influence Children. Diterjemahkan oleh Cony Semiawan, Jakarta: Restu Agung.

Fitri, S., Syahputra, E., \& Syahputra, H. (2019). Blended Learning Rotation Model of Cognitive Conflict Strategy to Improve Mathematical Resilience in High School Students. International Journal of Scientific \& Technology Research, 1 (1).

Fitri, S., \& Zahari, C.L. (2019). The implementation of blended learning to improve understanding of mathematics. The Sixth Seminar Nasional Pendidikan Matematika Universitas Ahmad Dahlan 2018: IOP Conf. Series: Journal of Physics: Conf. Series 1188 (2019) 012109, 2018, doi:10.1088/1742-6596/1188/1/012109.

Hudojo, H. (2005). Pengembangan Kurikulum dan Pembelajaran Matematika.Malang: Universitas Negeri Malang.

Landong, A., Surya, E., dan Syahputra, E. (2017). Echancement of Visual Thinking Ability in Mathematical Problem's Solving to Estabilish Student's Positicve Character. Researchgate.

Nehe, M., Surya, E., dan Syahputra, E. (2017). Creative Thinking Ability to Solving Equation and Non-Equation of Linear Single Variable in VII Grade Junior High School. IJARIIE, 3 (2).

Purba, E. N., Surya, E., dan Syahputra, E. (2017). Analisis Kemampuan Berpikir Kreatif Siswa Melalui Pemecahan Masalah Pada Materi FPB dan KPK. Researchgate.

Putri, J. H., Syahputra, E., dan Surya, E. (2017). Improving Student's Achievement in Problem Solving Ability by Using Problem Based Learning Model in Grade VIII Students of SMP Negeri 2 Lubuk Pakam. Reseacrhgate.

Simbolon, M., Manullang, M., Surya, E., dan Syahputra, E. 2017. The Effort to Improving the Critical Thinking student's Ability Through Problem Solving Learning Strategy by Using Macromedia Flash at SMP Negeri 5 Padang Bolak. Novelty Journal, 4 (1), p. 82-90.

Sinaga, D. Y., Surya, E., dan Syahputra, E. (2017). Pengaruh Pendekatan Realistic Mathematics Education (RME) Dengan Kemampuan Komunikasi Matematis Siswa Berbasis Problem Solving. Researchgate.

Siregar, N., Surya, E., dan Syahputra, E. (2017). Pengaruh Strategi Think-Thank-Write Terhadap Pemecahan Masalah Matematis Siswa Pokok Bahasan Kubus dan Balok.

Sofiyah, K., Surya, E., dan Syahputra, E. (2017). Membangun Kemampuan Pemecahan Masalah dan kemandirian Belajar Siswa Melalui Pembelajaran Geometri Berbasis Pendidikan Matematika Realistik. Researchgate.

Syahputra, E. (2016). StatistikaTerapan. Medan: Unimed Press.

Wijaya, A. 2012. Pendekatan Matematika Realistik. Yogyakarta: Graha Ilmu. 